\title{
Etkileşimsel Adaletin Çalışanların Seslilik Davranışı Üzerine Etkisi: Negatif Duyguların Aracılık Rolü

\author{
(The Effect of Interactional Justice on Employee Voice Behavior: The Mediating Role of
} Negative Emotions)
}

\author{
Ali ACARAY iD a \\ a Fındıklı Uygulamalı Bilimler Yüksekokulu, Recep Tayyip Erdoğan Üniversitesi, Rize, Türkiye. aliacaray@hotmail.com
}

\begin{tabular}{|c|c|}
\hline MAKALE BILGİSİ & ÖZET \\
\hline $\begin{array}{l}\text { Anahtar Kelimeler: } \\
\text { Etkilesimsel adalet }\end{array}$ & $\begin{array}{l}\text { Amaç - Bu çalışmanın amacı, etkileşimsel adaletin çalışanların seslilik davranışına etkisini } \\
\text { ve bu etkide negatif duyguların aracı rolünü incelemektir }\end{array}$ \\
\hline $\begin{array}{l}\text { Seslilik davranışı } \\
\text { Negatif duygular }\end{array}$ & $\begin{array}{l}\text { Yöntem - Çalışmanın verileri, bankacılık sektöründeki } 391 \text { çalışandan kolayda örnekleme } \\
\text { yöntemiyle anket tekniği kullanılarak toplanmıştır. Nicel analiz yöntemleri ile veriler } \\
\text { analiz edilmiştir. }\end{array}$ \\
\hline $\begin{array}{l}\text { Gönderilme Tarihi } 13 \text { Ocak } \\
2020 \\
\text { Revizyon Tarihi } 15 \text { Mart } 2020 \\
\text { Kabul Tarihi } 20 \text { Mart } 2020\end{array}$ & $\begin{array}{l}\text { Bulgular - Çalışmanın sonuçları, etkileşimsel adaletin çalışanların seslilik davranışlarını } \\
\text { artırdığını ve bu ilişkide kızgınlık ve korku gibi negatif duyguların kısmi aracılık rolü } \\
\text { üstlendiğini ortaya koymuştur. Bununla birlikte, etkileşimsel adaletin korku ve kızgınlık } \\
\text { gibi negatif duyguları zayıflattığı ve negatif duyguların da seslilik davranışlarını azalttığı } \\
\text { tespit edilmiştir. }\end{array}$ \\
\hline 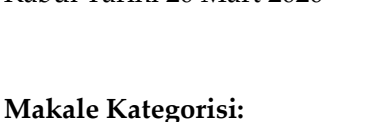 & $\begin{array}{l}\text { Tartışma - Etkileşimsel adaletin, çalışanların seslilik davranışına pozitif etkisinde korku ve } \\
\text { kızgınlık duygularının aracı role sahip olduğu ve örgütlerde seslilik davranışlarını } \\
\text { yönetmede yöneticiler için önemli bir yönetsel faktör olduğu ortaya çıkmıştır. }\end{array}$ \\
\hline
\end{tabular}

Araştırma Makalesi

\begin{tabular}{|c|c|}
\hline ARTICLE INFO & ABSTRACT \\
\hline $\begin{array}{l}\text { Keywords: } \\
\text { Interactional justice }\end{array}$ & $\begin{array}{l}\text { Purpose - The aim of this study is to investigate the effect of interactional justice on employee voice } \\
\text { and the mediating role of negative emotions on this effect. }\end{array}$ \\
\hline $\begin{array}{l}\text { Employee voice behavior } \\
\text { Negative emotions }\end{array}$ & $\begin{array}{l}\text { Design/methodology/approach - The data of the study were collected from } 391 \text { employees in the } \\
\text { banking sector by using convenience sampling method and survey technique. Data were analyzed } \\
\text { by quantitative analysis methods. }\end{array}$ \\
\hline $\begin{array}{l}\text { Received } 13 \text { January } 2020 \\
\text { Revised } 15 \text { March } 2020 \\
\text { Accepted } 20 \text { March } 2020\end{array}$ & $\begin{array}{l}\text { Findings - The results of the study revealed that interactional justice increased the employee voice } \\
\text { behavior and negative emotions such as anger and fear had a partly mediated role on this } \\
\text { relationship. However, interactional justice weakened negative emotions such as fear and anger, and } \\
\text { negative emotions reduced employee voice behaviors. }\end{array}$ \\
\hline $\begin{array}{l}\text { Article Classification: } \\
\text { Research Article }\end{array}$ & $\begin{array}{l}\text { Discussion - Negative emotions such as fear and anger had a mediating role on the positive effect } \\
\text { of interactional justice on voice behavior. The results showed that the perception of interactional } \\
\text { justice is an important managerial factor for managers to manage employee voice behavior in } \\
\text { organizations. }\end{array}$ \\
\hline
\end{tabular}

\section{Giriș}

Günümüzde örgütlerin, rekabet avantajını sadece ölçek ekonomisine bağlı kalmaktan ziyade bilgi tabanlarını genişleterek kazanabileceklerine ilişkin artan farkındalıklarının (Takeuchi vd., 2012) bir sonucu olarak, yapıcı öneri ve fikirleri olan çalışanlara sahip olmaları önemli hale gelmiştir (Çetin ve Çakmakçı, 2012; Detert ve Burris, 2007; Morrison ve Milliken, 2000). Çünkü bu çalışanların “diğerleri ile aynı fikirde olmadıklarında bile, mevcut uygulamalarda gelişim sağlamak için yenilikçi önerilerde bulunması" anlamına gelen seslilik davranışları (Van Dyne ve LePine, 1998) örgütlerdeki süreçlerin, ürünlerin ve hizmetlerin iyileştirilmesini

\section{Önerilen Atıf/Suggested Citation}

Acaray, A. (2020). Etkileşimsel Adaletin Çalışanların Seslilik Davranışı Üzerine Etkisi: Negatif Duyguların Aracılık Rolü, İşletme Araştırmaları Dergisi, 12 (1), 663-675. 


\section{A. Acaray $12 / 1(2020) 663-675$}

sağlayan temel kaynaklardan birisidir (Botero ve Van Dyne, 2009). Örgütler de çevreleri dinamik olduğunda ve yeni fikirlerin, gelişimin sürekliliğini kolaylaştırdığı durumlarda (Van Dyne ve LePine, 1998), çalışanlarından daha fazla yenilikçi fikirler ortaya koymalarını, inisiyatif almalarını, sorumluluk üstlenmelerini beklemektedir (Nikolaou vd., 2008). Dolayısıyla, seslilik davranışını cesaretlendiren uygulamalar içerisinde olmak gerekmektedir (Arslan ve Yener, 2016). Ancak seslilik davranışının artan önemine rağmen, çalışanların görüş ve düşüncelerini açık biçimde üstleriyle paylaşmaları halinde bunun karşılığında misilleme ile karşılaşabileceği, olumsuz biri olarak etiketlenebileceği, kariyerleri açısından olumsuz olabileceğini düşünerek yöneticilerine güvenmemekte ve seslilikten uzaklaşabilmektedirler (Durak, 2013; Detert ve Edmondson, 2011; Detert ve Burris, 2007; Morrison ve Milliken, 2000). Buna karş1lık, Botero ve Van Dyne (2009), lider-üye etkileşiminin yüksekliğinde çalışanların görüş ve önerilerini yöneticilerine aktarmada daha fazla iletişim imkânına sahip olduklarını ifade etmiştir. Dolayısıyla yönetici ve çalışan arasındaki iletişimin ve etkileşimin niteliğinin çalışanların seslilik davranışlarını nasıl etkileyebileceğinin incelenmesi önem arz etmektedir.

Yöneticilerin örgütteki prosedürlerin uygulanmasında çalışanlara dürüst olması, değer vermesi, saygı duyması ve onları bilgilendirmesi (Özçınar vd., 2015) anlamına gelen etkileşimsel adalete ilişkin çalışanların algılamaları onların tutum ve davranışları üzerinde etkili olabilecektir. Çünkü yöneticilerin dağıtım kararlarının alınmasına dair süreçlerin uygulanışındaki farklılıkları (örn. ödüllendirme süreçlerinin birimlerdeki yöneticiler tarafından farklı uygulanması), çalışanlarda adaletsizlik algısı oluşturarak farklı tepkilerin ortaya çıkmasına yol açabilecektir (Şeşen, 2010). Buna karşılık yöneticilerin çalışanları ile olan ilişkilerindeki etkileşimsel adaleti ise, çalışanlara örgüt için önemli olduğu mesajını da iletebilecektir (Güzel ve Ayazlar, 2014). Adams'ın (1963) Eşitlik Teorisi de, eşitsizliğin çalışanları bilişsel ve davranışsal olarak çeşitli tepkiler vermeye motive edebileceğini ileri sürmektedir.

İlgili yazında, etkileşimsel adaletin çalışmanın bağımlı değişkeni olan seslilik davranışına ve bununla ilgili yakın değişkenlere etkisine dair çeşitli çalışmalar mevcuttur. Kişilerarası güvenin işgören sesliliğini artırdığı (Derin, 2017), etkileşimsel adaletin ihmalkarlığı ve agresif sesliliği azalttığ1 (VanYperen vd., 2000), bilgi paylaşma davranışını (Demirel ve Seçkin, 2011) ve çalışanların sesliliğini artırdığı (Eryeşil, 2018; Dustar ve Esmailzadeh, 2014; Takeuchi vd., 2012), üretkenlik karşıtı iş davranışlarını azalttığı (Polatcı ve Özçalık, 2015; Roy vd., 2012) yapılan çalışmalarda tespit edilmiştir. Yazındaki etkileşimsel adalet ile çalışanların seslilik davranışları ilişkisini ele alan çalışmaların varlığına rağmen, söz konusu ilişkide hangi faktörlerin etkili olabileceğinin açıklanması gerekmektedir. Çünkü algılanan eşitsizlik halinde çalışanların çeşitli olumsuz duygusal tepkileri olabilmekte ve bu tepkilerin yönlendiriciliğinde ortaya çıkabilecek gerilimi azaltabilmek için çalışanlar örgüte sağladıkları girdileri azaltma yoluna gidebilmektedirler (Mcshane ve Von Glinow, 2014). Dolayısıyla çalışanların negatif duygularının, etkileşimsel adalet ile seslilik davranışları arasında aracılık rolü üstlenebileceği beklenmektedir.

Bu çalışmanın temel amacı, etkileşimsel adaletin çalışanların seslilik davranışına etkisini ve bu etkide negatif duyguların -korku ve kızgınlık- aracılık rolünü incelemektir. Çalışmanın örneklemi, bankacılık sektörü çalışanlarından seçilmiştir. Bu sektörün uygulama alanı olarak seçilmesinin gerekçesi ise, yaşanan yoğun rekabetin bir sonucu olarak müşteri istek ve beklentilerinin en hızlı ve en uygun koşullarda sağlanması için hizmet kalitesinin artırılması, şikâyetlerin etkin yönetilmesi, yenilikçi ürün ve hizmetlerin çeşitlendirilmesi ve geliştirilmesinde (örn. müşterilerin internet bankacılığından pek çok işlemi yapabilmesi, bankamatiklerden para üstü alabilmesi, barkod okuma ve parmak izi tanıma gibi özellikleri kullanması) çalışanların yapıcı, yenilikçi ve yaratıcı görüş ve fikirlerine ihtiyaç duyulmasıdır. Söz konusu alanlarda iyileştirmeler ve dönüşümler yapılabilmesinde çalışanların seslilik davranışları önem arz etmektedir. Ayrıca bu çalışmanın, çalışanların seslilik davranışları üzerinde etkili olabilecek faktörleri ortaya koyarak ve etkileme mekanizmasını açıklayarak teorik açıdan, yöneticilerin seslilik davranışlarının ortaya çıkarılabilmesinde hangi uygulamalar içerisinde olması ya da olmamasını belirterek de pratik açıdan katkılarının olabileceği beklenmektedir.

\section{Kavramsal Çerçeve ve Hipotez Geliştirme}

\subsection{Etkileşimsel Adalet}

Örgütsel adalet ile ilgili çalışmalar Adams'ın $(1963,1965)$ Eşitlik Teorisine dayanmakta; Adams da teorisini açıklarken, çalışanların yaptıkları çalışmalar neticesinde kazandıklarını, diğer çalışanların kazandıklarıyla 


\section{A. Acaray $12 / 1(2020) 663-675$}

karşılaştıracakları düşüncesine dayanmıştır (Demirel ve Seçkin, 2011). Çalışanlar bu karşılaştırma neticesinde örgütüne ve yöneticilerine ilişkin çeşitli tutumlar geliştirmekte; bu tutumların gelişiminde de örgütteki adaletle ilgili algılaması önemli bir rol oynamaktadır (Özdevecioğlu, 2003). Örgütsel adalet, çalışanların işyeri çıtıları ve süreçlerinin uygunluğu ile ilgili değerlendirme ve eşitlik algısıdır (Greenberg ve Colquitt, 2005). Başka bir tanımda ise örgütsel adalet, çalışanların, örgütlerinin kendilerine adil biçimde davrandıklarına ilişkin bakış açılarıdır (Güzel ve Ayazlar, 2014). Daha geniş bir tanımla ise örgütsel adalet ücret, ödül, ceza ve terfilerin örgütte nasıl dağıtıldığının, buradaki kararların nasıl alındığının veya bu kararlarının çalışanlara nasıl ifade edildiğinin çalışanlarda oluşturduğu algılamadır (İçerli, 2010). İlgili yazında örgütsel adaletin dağıtımsal, prosedürel ve etkileşimsel adalet olmak üzere üç boyutlu bir yapıdan meydana geldiği kabul edilmektedir (Roy vd., 2012; Demirel ve Seçkin, 2011). Örgütsel adaletin ilk bileşeni olan dağıtımsal adalet, Adams'ın Eşitlik Teorisine (1965) dayanarak geliştirilmiş olup, çalışanların örgüte katkıları karşılığında aldıklarını diğer arkadaşlarının katkıları ve aldıkları ile karşılaştırarak algıladıkları eşitliktir (Roy vd., 2012). Adaletle ilgili çalışmaların artmasıyla birlikte dağıtımsal adaletin yanında, çalışanların elde ettikleri kazanımların belirlenmesindeki karar verme süreçlerinde uygulanan kriterlerin adil olarak değerlendirmesi anlamına gelen prosedürel adalet (Thibaut ve Walker, 1975) türü geliştirilmiştir. Daha sonra ise Bies ve Moag (1986), bu iki yapıdan farklı olarak, örgütsel süreçlerin işleyişi esnasında çalışanlar ve yöneticiler arasındaki ilişkide eşitlik algılaması anlamına gelen etkileşimsel adaleti ortaya koymuşlardır. Başka bir ifade ile etkileşimsel adalet, örgütsel işlemlerin uygulanması sürecinde çalışanların karşılaştığı tutum ve davranışlarının niteliğidir (Bies, 2001). Dolayısıyla etkileşimsel adalet, çalışanlar arasındaki ilişkinin niteliğine vurgu yapar (Şeşen ve Basım, 2010).

Greenberg (1999) çalışmasında, etkileşimsel adaleti bilgisel adalet ve kişilerarası adalet olarak ikiye ayırmıştır: Bilgisel adalet, kazanımların dağıtımı ve dağıtımında kullanılan süreçlerle ilgili olarak çalışanların ne kadar bilgilendirildiği ve onlara ne kadar açılama yapıldığı ile ilgili çalışanın algılaması iken; kişilerarası adalet ise kazanımları belirleyen yöneticilerin çalışanlara ne derecede nazik ve saygılı olduğu ve değer verdiğine dair etkileşimin niteliğinin çalışanlar tarafından algılanmasıdır. Bu çalışmada, örgütsel adaletin etkileşimsel adalet boyutu bağımsız değişken olarak alınmıştır.

\subsection{Seslilik Davranışı}

Seslilik, Hirschman'ın 1970 yılında "bir çalışanın sakıncalı bir durumdan uzaklaşmak yerine söz konusu durumu değiştirmeye yönelik girişimde bulunması davranışı" biçiminde yaptığı tanımla yazındaki yerini almıştır (Derin, 2017). Seslilik davranışına yönelik birçok tanım yapılmıştır. Van Dyne ve LePine (1998) sesliliği, mevcut durumu düzeltmeye yönelik konuşması ve statükoyu sorgulaması şeklinde tanımlayarak seslilik davranışının sadece eleştirmekten ziyade iyileştirme sağlamak için yapıcı bir sorgulamayı da kapsadığını belirtmiştir. Ayrıca seslilik, çalışanların örgütsel işleyişe etkide bulunmak için gönüllük çerçevesinde görüşlerini ifade etmesi (Çetin ve Çakmakçı, 2012) olarak da tanımlanmıştır. Seslilik davranışı, çalışanların iş ile ilgili olarak hoşnutsuzluklarını üstlerine ifade etmesi yanında çalışanların karar alma sürecine katılarak düşüncelerini ifade etmesi olarak da tanımlanmıştır (Arslan ve Yener, 2016). Dolayısıyla seslilik davranışı temelde yapıcı bir ekstra rol davranışıdır (Van Dyne ve LePine, 1998).

Etkileşimsel adalet, yöneticilerle çalışanlar arasında yaşanan sosyal deneyimlerin sonucunda ve ilişkilerin belli bir kalitede olması durumunda ortaya çıkmaktadır (Demirel ve Seçkin, 2011). Etkileşimsel adalet, günlük çalışma ortamında dağıtımsal ve prosedürel adalet unsurlarına göre daha yaygın olması nedeniyle, çalışanlar örgütsel değişimleri etkileşimsel adalet temelinde değerlendireceklerdir (Roy vd., 2012). Söz konusu değerlendirmeler neticesinde çalışanlar olumsuz algılamalar içerisine girerlerse, yönetici ile arasındaki etkileşimin niteliğinde bir düşüş meydana gelerek kendi takdirlerine bağlı olarak gerçekleştirdikleri seslilik davranışlarını azaltabilecektir. Seslilik davranışı temelde riskli bir davranış olması nedeniyle, ortaya çıkması yönetici eylemlerinin çalışanda adalet algılamasını oluşturarak güven tesis etmesi halinde mümkündür. Başka bir deyişle yönetici çalışan ilişkileri bir güven temelinde ilerliyorsa, taraflar karşılıklı anlayış, destekleme ve yardım etme davranışları içerisinde olacaklardır (Özbek, 2004). Yeşil ve arkadaşları (2018) etkileşimsel adaletin çalışanın kendisini koruma amaçlı olarak sessizliğe girmesini azalttığını tespit etmişlerdir. Eroğluer ve Erselcan (2017) da etkileşimsel adaletin çalışanların sessizliklerini azalttığını; Şeşen ve Basım (2010) da etkileşimsel adaletin örgütsel vatandaşlık davranışını artırdığını ortaya koymuşlardır. Bununla birlikte etkileşimsel adalet ile çalışanların seslilik davranışı arasındaki ilişki, Blau'nun (1964) Sosyal Değişim Teorisine dayanarak da açılanabilir. Teori, taraflardan biri diğerine olumlu (örn, adaletli bir ortam sağladığında) ya da 


\section{A. Acaray $12 / 1(2020) 663-675$}

olumsuz (örn, verilen sözleri tutamadığında) bir şey sağladığında, diğer tarafın da buna olumlu (örn, pozitif davranışlarda bulunacağı) ya da olumsuz olarak (örn, pozitif davranışları azaltacağı) cevap vereceği düşüncesine dayanmaktadır. Dolayısıyla çalışanların yöneticileri ile aralarındaki hem bilgisel hem de kişilerarası adalet algılamaları zedelenirse, sosyal değişim teorisinin temel düşüncesine uygun olarak seslilik davranışlarını geri çekebileceklerdir. Çalışanlar örgütlerinde ne kadar hakkaniyetli uygulamalar görürlerse, daha fazla gönüllü davranışlar içerisinde olma konusunda kendilerini sorumlu hissedecekler (Yeşil vd., 2018) ya da adil olmayan uygulama ve davranışları gördüklerinde ise gönüllü davranışlarını ya azaltacaklar ya da gizleyeceklerdir (İşbaşı, 2001). Dolayısıyla yapılan açıklamalardan ve ilgili teorinin varsayımından hareketle aşağıdaki hipotez ileri sürülmüştür:

H1: Etkileşimsel adalet seslilik davranışı üzerinde etkiye sahiptir.

\subsection{Negatif Duygular}

Duygular, kararları ve eylemleri harekete geçiren önemli tetikleyicilerden biri (Barutçugil, 2004) olduğu için örgütlerdeki davranışın açıklanmasında da önemli bir konudur (Özkalp ve Cengiz, 2003). Bireylerin duygu yapıları pozitif ve negatif duygular şeklinde ikiye ayrılmaktadır. Pozitif duygusallık, olumlu bir duygusal duruma olan eğilimi, negatif duygusallık ise olaylara ilişkin olumsuz eğilimi ifade etmektedir (Özkalp ve Cengiz, 2003). Pozitif duygusallığın kapsamında mutluluk, umut gibi bireyin kendisini iyi hissetmesinde rolü olan duygular, negatif duygusallığın kapsamında ise bireyin kendisini kötü hissetmesinde rolü olan öfke, nefret, korku, kızgınlık gibi duygular yer almaktadır (Özdevecioğlu, 2004). Çalışma ortamında bu negatif duygular çatışma, işten çıkma, stres ve tükenmişlik gibi olumsuz davranışların temelinde yer almaktadır (Töremen ve Çankaya, 2008).

Etkileşimsel adalet algısının ortaya çıkmasında yöneticilerin karar alırken çalışanları ile bilgi paylaşımında bulunup bulunmayacağı ve bilginin çalışanlara nasıl ve hangi çerçevede aktarıldığ 1 veya aktarılacağı önemli bir konudur. Çalışanlar alınan kararları değerlendirmede yöneticilerin diğer arkadaşlarıyla kurduğu iletişimi, kendisi ile de kurmasını bekler ve bu iletişimde adalet bulmaya çalışır. Alınan kararlarda tam bir açıklama yapılmamış ve endişeleri saygı ile karşılanmamış ise adaletsizlik algısı hissederek yöneticilerine dair çeşitli duygusal tepkiler geliştirebilecektir (Mcshane ve Von Glinow, 2014; Özdevecioğlu 2003). Negatif duygular, etkileşimsel adalet süreçlerinde önemli bir rol oynar (Roy vd., 2012). Skarlicki ve Folger (1997), adil olmayan prosedürlerin algılanmasının öfke, kızgınlık ve hakarete uğrama gibi negatif duyguları ortaya çıarabileceğini ifade etmiştir. Polatcı ve Özçalık (2015), çalışanların dağıtımsal adalet algılarının negatif duygusallığı ve Roy ve arkadaşları (2012), etkileşimsel adalet algısının çalışanların öfke ve kızgınlık duygularını azalttığını tespit etmişlerdir. Fox ve arkadaşları (2001) da dağıtımsal ile prosedürel adaletin pozitif duygularla pozitif, negatif duygularla negatif ilişki içerisinde olduklarını ortaya koymuşlardır. Ayrıca etkileşimsel adalet ile negatif duygular arasındaki ilişki Duygusal Olaylar Teorisi (Weiss ve Cropanzano, 1996) açıklanabilir. Teori, bireylerin yaşadıkları ve etkilendikleri olayların, onların duygusal tepkilerini ve davranışlarını etkileyebileceğini ileri sürmektedir (Weiss ve Cropanzano, 1996). Eğer çalışanlar yöneticileriyle olan etkileşimlerinde adaletsizlik algılarlarsa, bu duruma korku ve kızgınlı gibi negatif duygusal tepkilerle duygusal olaylar teorisi çerçevesinde karşılık verebileceklerdir. Dolayısıyla yapılan açıklamalar, çalışmaların ortaya koydukları ve ilgili teorinin varsayımından hareketle aşağıdaki hipotez ileri sürülmüştür:

H2: Etkileşimsel adalet negatif duygular (H2a: Korku; H2b: Kızgınlık) üzerinde etkiye sahiptir.

Çalışanların sahip oldukları negatif duyguların onların seslilik davranışları üzerinde azaltıcı bir etkiye sahip olabileceği beklentisi, Duygusal Olaylar Teorisi (Weiss ve Cropanzano, 1996) ile açılanabilir. Teoriye göre, çalışanların deneyimledikleri korku ve kızgınlık gibi negatif duyguların onların seslilik davranışlarını azaltabileceği ileri sürülebilir. Özdevecioğlu (2004) da örgütsel davranışların temelinde kişisel özellikler ve örgütün özelliklerinin yanında yaşanılan duygusal olayların da yer aldığını ifade etmiştir. Dolayısıyla ErolKorkmaz (2014), çalışma ortamında yaşanılan olumlu duyguların çalışanların vatandaşlık davranışlarına, olumsuz duyguların da üretim karşıtı davranışlara neden olabileceğini ileri sürmüştür. Bu bağlamda yapılan açıklamalardan ve ilgili teorinin varsayımından hareketle aşağıdaki hipotez ileri sürülmüştür:

H3: Negatif duygular (H3a: Korku; H3b: Kızgınlık) seslilik davranışı üzerinde etkiye sahiptir. 


\subsection{Negatif Duyguların, Etkileşimsel Adalet ile Seslilik Davranışı Arasındaki İlişkide Aracılık Etkisi}

Örgütlerde adil olmayan durumlar algılandığında çalışanlar, bu durumlara duyguları ile derhal tepkiler verecekler ve bu tepkiler de çalışanları, sonraki yapacakları davranışlarda motive edebilecektir (Roy vd., 2012). Çalışanların yöneticileri ile olan iletişiminde algıladıkları adaletsizlik negatif duygularını güçlendirerek davranışsal çıktılarını etkileyebilecektir. Başka bir deyişle, etkileşimsel adaletsizlik korku ve kızgınlık gibi duyguları artırarak seslilik davranışını azaltabilecektir. VanYperen ve arkadaşları (2000) da, çalışanların adaletsizlik algılamasının negatif duyguları artırarak yıkıcı davranışsal tepkiler ortaya çıkarabileceğini ileri sürmüştür. Fox ve arkadaşları (2001) negatif duyguların adalet algıları ile üretkenlik karşıtı iş davranışları arasında, Roy ve arkadaşları (2012) da etkileşimsel adalet ile üretkenlik karşıtı iş davranışı arasında aracılık rolü üstlendiğini tespit etmişlerdir. Bu bağlamda negatif duygular, etkileşimsel adalet ile seslilik davranışı arasındaki ilişkiye aracılık edebilir.

H4: Negatif duygular (H4a: Korku; H4b: Kızgınlık), etkileşimsel adalet ile seslilik davranışı arasındaki ilişkide aracıllk etkisine sahiptir.

Etkileşimsel adaletin çalışanların seslilik davranışına etkisinde negatif duyguların (korku ve kızgınlık) aracılık etkisine dair beklenen ilişkileri ortaya koymak için ileri sürülen hipotezleri kapsayan araştırmanın modeli Şekil 1'de görülmektedir.

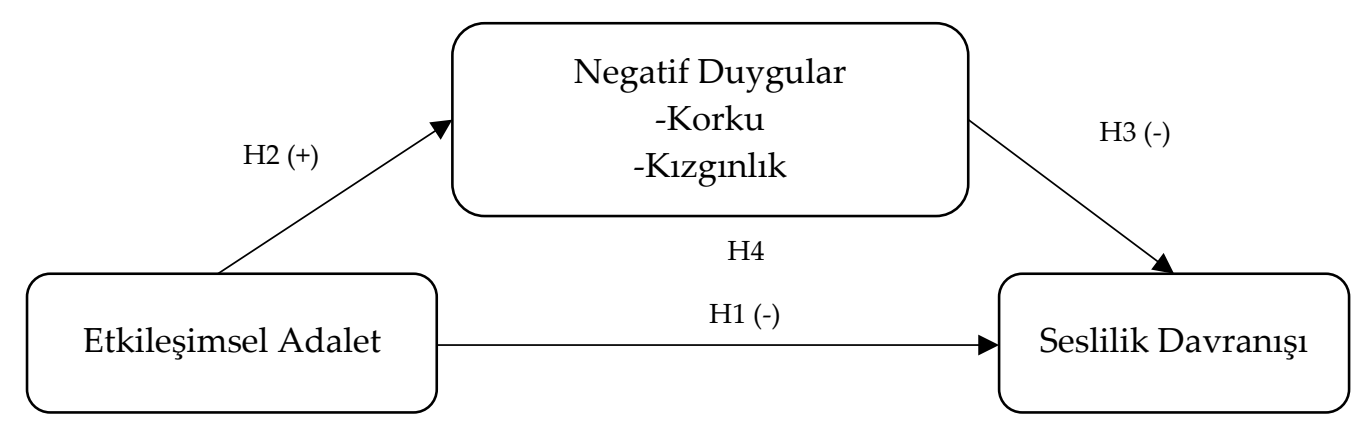

Şekil 1. Araştırmanın Modeli

\section{Yöntem}

\section{1. Örnekleme Süreci ve Demografik Sonuçlar}

Araştırmanın evreni, İstanbul ilinin Anadolu yakasında bulunan beş ilçesindeki farklı banka şubelerinde istihdam edilen çalışanlardır. Bankalardaki toplam 2637 adet çalışandan; yönetici pozisyonunda olmayan 1350 kişilik bir örneklem grubuna anket formları, kolayda örnekleme yöntemiyle dağıtılmıştır. Anketleri, toplam 466 çalışan doldurmuştur. Anketlerden 75 'i, tam olarak doldurulmaması ve tüm sorulara aynı cevapların verilmesi gibi nedenlerle kullanılmamıştır. Bu çalışmada kolayda örnekleme yönteminin seçilmesinin nedeni, verilere daha hızlı, kolay ve ekonomik biçimde ulaşma kolaylığı sağlamasıdır (Haşıloğlu vd., 2015; Malhotra, 2004). Analiz için uygun örneklem sayısı 391 olup, geri dönüşüm oranı \% 28,96 gerçekleşmiştir. Analize tabi tutulacak örneklemin büyüklüğ̈ için, 2.637 kişilik bir evrende \% 5 kabul edilebilir hata payı ve \% 95 güven aralığında 336 kişiye ihtiyaç olup (Yazıcıŏlu ve Erdoğan, 2004), ulaşılan örneklem sayısı bu sayının üzerindedir. Dolayısıyla 391 örneklem yeterlidir.

Araştırmaya katılan örneklemin, \% 55,7'si erkek, \% 74,4'ü lisans ve \% 20,0'si yüksek lisans mezunu, yaş ortalaması 33,61 (ss:6,73), \% 67,5'i evli olup; \% 42'si müşteri temsilcisi, \% 39,6'sı gişe çalışanı, \% 18,4'ü operasyon görevlisi ve kurumlarındaki çalışma süresi ise ortalama 8,33 yıl (ss:5,85) olarak ortaya çıkmıştır.

\subsection{Kullanılan Ölçekler}

Araştırmaya katılan örneklemin cinsiyet, eğitim durumu, yaş, medeni durumu, kurumdaki çalışma süresi ve görevi gibi demografik bilgilerinin öğrenilmesine ilişkin anketin başlangıcında çeşitli sorular sorulmuştur. 


\section{A. Acaray $12 / 1(2020) 663-675$}

Ayrıca örneklemin etkileşimsel adalet, negatif duygular ve seslilik gibi konulardaki algılamalarının ölçümüne dair toplam 25 adet soru sorulmuştur. Örneklemin demografik bilgiler haricindeki diğer ifadelere yönelik algilamaları 5'li likert tipinde (1=Kesinlikle katılmıyorum ve 5=Kesinlikle katılıyorum) ölçekler kullanılarak ölçülmüştür.

Çalışanların etkileşimsel adalet algılarının ölçümünde Colquitt'in (2001) örgütsel adalet ölçeğinin etkileşimsel alt boyutuna ilişkin 9 ifadesi kullanılmıştır. İfadelerden sekizi olumlu, birisi ise olumsuz olarak sorulmuştur. Olumsuz olan ifade analizde ters skorlanmıştır. İlgili yazında etkileşimsel adalet; bilgisel adalet ve kişilerarası adalet alt boyutlarından oluşmaktadır. Ancak bu çalışmada etkileşimsel adalet, alt boyutlara ayrılmamıştır. Etkileşimsel adaletin örnek ifadelerinden birisi "Yöneticim, işimle ilgili bilgi aktarırken herkesin anlayabileceği dilden konuşur" şeklindedir. Özmen ve arkadaşlarının (2007) çalışmasında, etkileşimsel adaletin güvenilirliği 0,88 olarak hesaplanmıştır.

Çalışanların negatif duygularının (korku ve kızgınlık) ölçümünde Gaudreau ve arkadaşlarının (2003) çalışmalarında kullandıkları 10 ifade iki alt boyuttan oluşan negatif duygular (NAS) ölçeğinden yararlanılmıştır. Korku alt boyutuna ilişkin örnek ifadelerden birisi “Ürkmüş hissediyorum” iken, kızgınlık alt boyutuna ilişkin örnek ifadelerden birisi ise "Sinirli hissediyorum" şeklindedir. Ölçeğin kullanıldığı çalışmada güvenilirlikler korku alt boyutu için birinci örneklemde 0,76; ikinci örneklemde 0,74 ve kızgınlık alt boyutu için ise birinci örneklemde 0,81 ; ikinci örneklemde 0,82 olarak hesaplanmıştır.

Çalışanların seslilik davranışlarının ölçümünde Van Dyne ve LePine'nin (1998) geliştirdiği ve Çetin ve Çakmakçı'nın (2012) Türkçe'ye uyarladığı 6 ifade ve tek boyutlu ölçek kullanılmıştır. Ölçeğin örnek ifadelerinden birisi "Banka şubesindeki diğer arkadaşlarımın benimle aynı görüşte olmadığını bilsem de iş ile ilgili konulardaki düşüncelerimi onlarla paylaşırım" şeklindedir. Ölçek uyarlamasının yapıldığı çalışmada güvenilirlik 0,87 olarak hesaplanmıştır.

\section{Bulgular}

\section{1. Ölçeklerin Geçerlilik ve Güvenilirlik Analizleri}

Ölçüm geçerliliğinde keşfedici faktör analizi yapılmış ve güvenilirliğinde ise Cronbach Alfa değerleri hesaplanmıştır. Tablo 1'de araştırma ölçeklerinin faktör yükleri ile geçerlilik ve güvenilirlik analizlerinde ulaşılan sonuçlar sunulmaktadır. Araştırma verilerinin faktör analizine yeterli olup olmadığının tespitinde KMO değerlerine bakılmaktadır. Hesaplanan KMO değerleri etkileşimsel adalet ölçeği için 0,916; negatif duygular için 0,870 ve seslilik davranışı için ise 0,886 olarak ortaya çıkmıştır. Bu değerler de, KMO için eşik değer olan 0,50'i (Field, 2000) geçtikleri için faktör analizi yapılmıştır. Faktör analizi ise çıkarım yönteminde temel bileşen analizi, rotasyon yönteminde ise Varimax kullanılarak yapılmıştır. Keşfedici faktör analizinde etkileşimsel adaletin sadece bir ifadesi (Yöneticim haksız yorum ve eleştiriler yöneltir) farklı bir faktörde toplanmasından ötürü analize katılmamıştır. Çalışmada kullanılan her üç ölçek de yazına uygun biçimde ortaya çıkmıştır (etkileşimsel adalet ile seslilik davranışı birer boyut ve negatif duygular ise korku ve kızgınlık olarak iki boyut). Etkileşimsel adaletin kalan sekiz ifadesi toplam varyansın \% 69,88'ini, negatif duyguların korku alt boyutunun beş ifadesi toplam varyansın \% 36,11'ini ve kızgınlık alt boyutunun beş ifadesi toplam varyansın \% 32,10'unu ve seslilik davranışının altı ifadesi ise toplam varyansın \% 72,05'ini açıkladığı görülmüştür. Bununla birlikte tüm ölçeklerin güvenilirlik değerleri 0,70'in üzeri olarak ortaya çıkmış olması nedeniyle ölçekler güvenilir olarak değerlendirilmiştir (Kalaycı, 2008). Söz konusu güvenilirliklere ilişkin sonuçlar da Tablo 1'de sunulmaktadır.

Tablo 1. Ölçeklerin Faktör Analiz ve Güvenilirlik Sonuçları

\begin{tabular}{|c|c|c|c|c|c|}
\hline : & İfadeler & 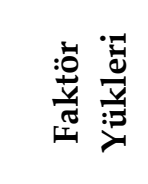 & 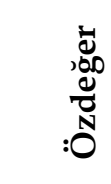 & 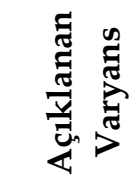 & 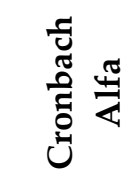 \\
\hline \multirow{4}{*}{ 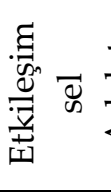 } & Etkileşimsel Adalet (EA) & & 5,591 & 0,6988 & 0,938 \\
\hline & EA 1 & 0,849 & & & \\
\hline & EA 2 & 0,854 & & & \\
\hline & EA 3 & 0,868 & & & \\
\hline
\end{tabular}


A. Acaray 12/1 (2020) 663-675

\begin{tabular}{|l|l|l|l|l|l|}
\hline EA 4 & 0,840 & & & \\
\hline & EA 5 & 0,839 & & & \\
\hline & EA 6 & 0,830 & & & \\
\hline & EA 7 & 0,832 & & & \\
\hline & EA 8 & 0,773 & & & \\
\hline & EA 9 & $*$ & & & \\
\hline
\end{tabular}

Kaiser-Meyer-Olkin Örneklem Yeterliliği Ölçümü: 0,916; Bartlett Sınama Testi, Yaklaşık Ki-Kare Değeri: 2570,193; Serbestlik Derecesi: 28; Anlamlılık Düzeyi: 0,000

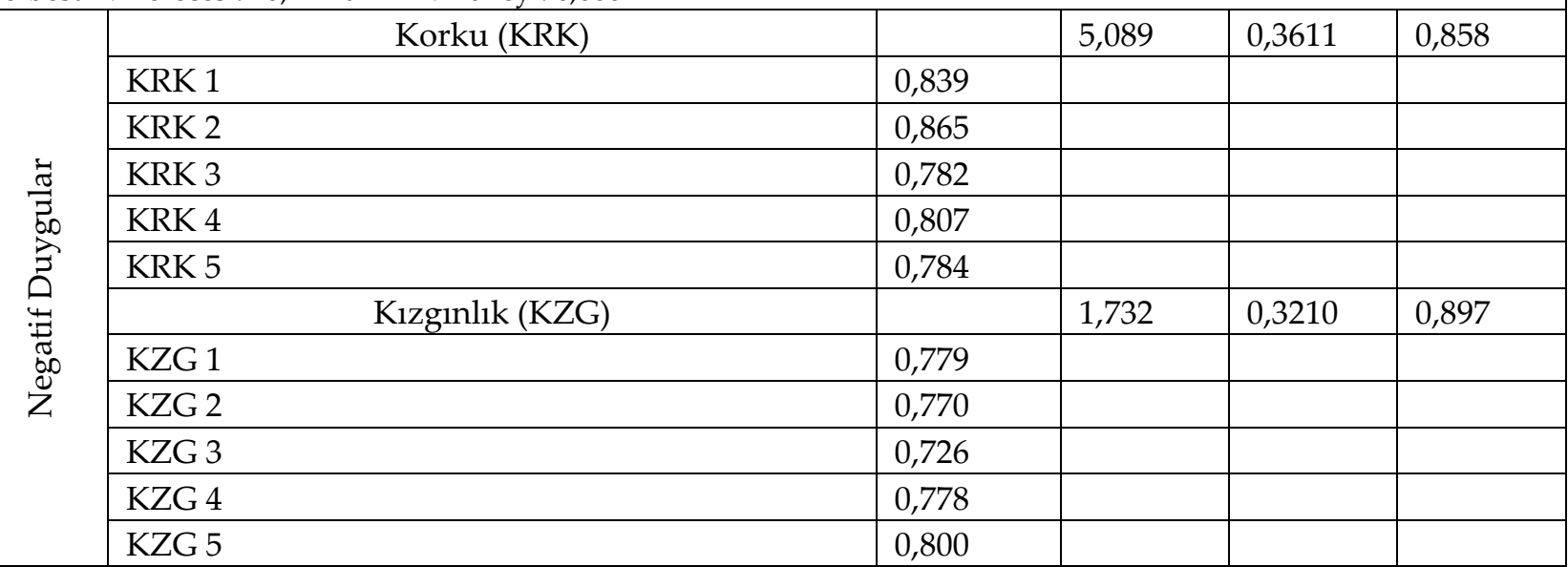

Kaiser-Meyer-Olkin Örneklem Yeterliliği Ölçümü: 0,870; Bartlett Sınama Testi, Yaklaşık Ki-Kare Değeri: 2284,748; Serbestlik Derecesi: 45; Anlamlılık Düzeyi: 0,000

\begin{tabular}{|c|c|c|c|c|c|}
\hline \multirow{7}{*}{ 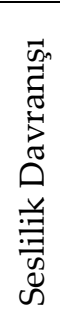 } & Seslilik Davranışı (SD) & & \multirow[t]{2}{*}{4,323} & \multirow[t]{2}{*}{0,7205} & \multirow[t]{2}{*}{0,921} \\
\hline & SD 1 & 0,794 & & & \\
\hline & SD 2 & 0,845 & & & \\
\hline & SD 3 & 0,895 & & & \\
\hline & SD 4 & 0,877 & & & \\
\hline & SD 5 & 0,840 & & & \\
\hline & SD 6 & 0,839 & & & \\
\hline
\end{tabular}

Kaiser-Meyer-Olkin Örneklem Yeterliliği Ölçümü: 0,886; Bartlett Sınama Testi, Yaklaşık Ki-Kare Değeri: 1705,486; Serbestlik Derecesi: 15; Anlamllık Düzeyi: 0,000

*: Farklı bir faktörde toplandığı için analizin dışına bırakılmıştır.

\subsection{Hipotez Testleri}

Değişkenlerin kendi aralarındaki ilişkiler, korelasyon analizi ile ortaya konulmuştur. Ulaşılan sonuçlara göre (Tablo 2); etkileşimsel adalet ile seslilik davranışı $(\mathrm{r}=0,42, \mathrm{p}<0,01)$ arasında pozitif, etkileşimsel adalet ile korku duygusu $(r=-0,23, p<0,01)$ ve kızınlık duygusu $(r=-0,14, p<0,01)$ arasında negatif ve korku duygusu ile seslilik davranışı $(r=-0,20, p<0,01)$ ve kızgınlık duygusu ile seslilik davranışı $(r=-0,17, p<0,01)$ arasında ise negatif bir ilişki vardır.

Tablo 2. Korelasyonlara İlişkin Değerler

\begin{tabular}{|c|l|c|c|c|c|c|c|}
\hline Sıra & \multicolumn{1}{|c|}{ Değişkenler } & $\mathbf{1}$ & $\mathbf{2}$ & $\mathbf{3}$ & $\mathbf{4}$ & Ort. & Ss. \\
\hline 1 & Etkileşimsel Adalet & -- & & & & 3,93 & 0,8499 \\
\hline 2 & Seslilik Davranışı & $0,42^{* *}$ & -- & & & 3,63 & 0,8999 \\
\hline 3 & Korku & $-0,23^{* *}$ & $-0,20^{* *}$ & -- & & 1,45 & 0,7576 \\
\hline 4 & Kızgınlık & $-0,14^{* *}$ & $-0,17^{* *}$ & $0,49^{* *}$ & -- & 2,32 & 0,9308 \\
\hline
\end{tabular}

$\mathrm{N}: 391,{ }^{* *} 0,01 \mathrm{ve}^{*} 0,05$ seviyesinde korelasyonlar anlamlıdır. (çift taraflı).

Etkileşimsel adaletin çalışanların seslilik davranışına etkisinde negatif duyguların (korku ve kızgınlık) aracılık rolünün incelenmesinde regresyon analizi yapılmıştır. Regresyon analizine geçmeden önce, bağımsız ve aracı değişkenler arasında çoklu bağlantı (multicollinearity) probleminin ortaya çıkıp çıkmadığının kontrolü 


\section{A. Acaray $12 / 1(2020) 663-675$}

gerekmektedir. Kontrolde ise VIF (varyans büyütme faktörü) değerlerine bakılmakta ve hesaplanan değerin 10 'dan küçük olması gerekmektedir. Ayrıca verilerin otokorelasyona sahip olup olmadığı da kontrol edilmekte olup, burada da Durbin-Watson değerlerine bakılmakta ve hesaplanan değerin 1,50-2,50 arasında (Uslu ve Aktaş, 2017) olması gerekmektedir. Tablo 3'teki sonuçlarda VIF ve Durbin-Watson değerlerinin ilgili referans sınırlarını geçmediği görülmektedir.

Tablo 3. VIF ve Durbin-Watson Değerleri

\begin{tabular}{|c|c|c|c|c|}
\hline Hipotezler & Bağımlı Değişken & Bağımsız ve Aracı Değişkenler & VIF & $\begin{array}{l}\text { Durbin- } \\
\text { Watson }\end{array}$ \\
\hline H1 & Seslilik Davranışı & Etkileşimsel Adalet & 1,000 & 1,977 \\
\hline $\mathrm{H} 2 \mathrm{a}$ & Korku & Etkileşimsel Adalet & 1,000 & 1,501 \\
\hline H3a & Seslilik Davranışı & Korku & 1,000 & 1,883 \\
\hline $\mathrm{H} 4 \mathrm{a}$ & Seslilik Davranışı & $\begin{array}{l}\text { Etkileşimsel Adalet } \\
\text { Korku }\end{array}$ & $\begin{array}{l}1,054 \\
1,054\end{array}$ & 1,960 \\
\hline $\mathrm{H} 2 \mathrm{~b}$ & Kızgınlık & Etkileşimsel Adalet & 1,000 & 1,668 \\
\hline $\mathrm{H} 3 \mathrm{~b}$ & Seslilik Davranışı & Kızgınlık & 1,000 & 1,819 \\
\hline $\mathrm{H} 4 \mathrm{~b}$ & Seslilik Davranışı & $\begin{array}{l}\text { Etkileşimsel Adalet } \\
\text { Kızgınlık }\end{array}$ & $\begin{array}{l}1,019 \\
1,019\end{array}$ & 1,921 \\
\hline
\end{tabular}

Aracıllk rolünün incelenmesinde, Baron ve Kenny'nin (1986) üç koşuldan oluşan analiz yöntemi takip edilmiştir. Buna göre; a) bağımsız değişken (etkileşimsel adalet) aracı değişken (korku ve kızgınlık) üzerinde; b) aracı değişken (korku ve kızgınlık) bağımlı değişken (seslilik davranışı) üzerinde ve ayrıca c) bağımsız değişken (etkileşimsel adalet) bağımlı değişken (seslilik davranışı) üzerinde bir etkiye sahip olmalıdır. Bağımsız ile aracı değişkenin bağımlı değişkene birlikte etkisine bakıldığında ise ya bağımsız değişkenin etkisinde bir azalma ya da etkisinin tamamen ortadan kalkması gerekir. Başka bir anlatımla, bağımsız değişken bağımlı değişken üzerindeki etkisini yitirirse tam aracılık; bağımsız değişkenin bağımlı değişkene etkisinde bir azalma meydana gelirse kısmi aracılık etkisinin varlığı ileri sürülebilir. Bu açılamalara göre Şekil 2'deki aracilık etkisinin ortaya konulmasındaki yollara (etkiler) ilişkin analizler Tablo 4 ve 5'te gösterilmektedir. Negatif duyguların aracılık rolü, Hayes'in (2012) bootstrap yaklaşımına dayanan (5000 örneklem) SPSS'teki Process makrosu ile incelenmiştir. Söz konusu makroda toplam, doğrudan ve dolaylı etkilerin ortaya konulması yanı sıra aracı değişkenin bağımlı değişkene etkisi de incelenmektedir. Dolaylı etkinin anlamlılığı ise Bootstrap güven aralığı (BootLLCI - BootULCI) değerlerinin sıfırı (0) içerip içermediğine bakılarak ortaya konulmaktadır.

c (Toplam Etki)

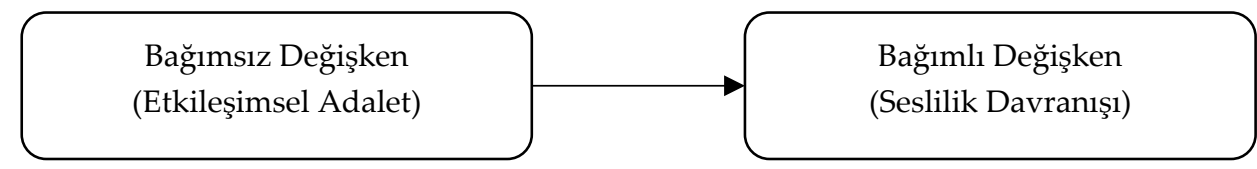

$c^{\prime}$ (Doğrudan Etki)

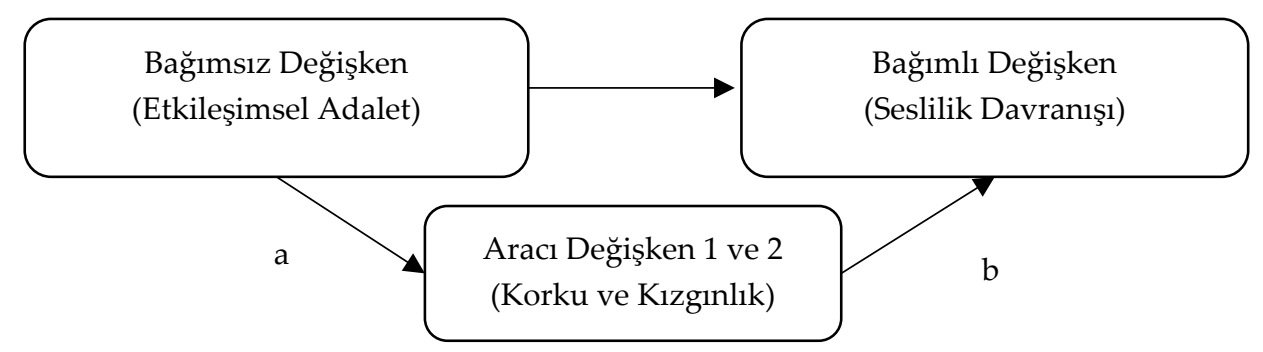

Şekil 2: Aracılık Etkisinin Ortaya Çıkışı 
A. Acaray 12/1 (2020) 663-675

Tablo 4. Korku Duygusunun Aracilık Etkisi

\begin{tabular}{|c|c|c|c|c|c|c|c|c|c|}
\hline \multicolumn{2}{|c|}{$\begin{array}{c}\text { a yolu } \\
(\mathrm{X} \rightarrow \mathrm{M} 1)\end{array}$} & \multicolumn{2}{|r|}{$\begin{array}{l}\text { b yolu } \\
(\mathrm{M} \rightarrow \mathrm{Y})\end{array}$} & \multicolumn{2}{|c|}{$\begin{array}{c}\text { c yolu } \\
(X \rightarrow Y \\
\text { Toplam Etki* })\end{array}$} & \multicolumn{2}{|c|}{$\begin{array}{c}c^{\prime} \text { yolu } \\
(X \rightarrow Y \\
\text { Doğrudan Etki })\end{array}$} & \multicolumn{2}{|r|}{$\begin{array}{c}(\mathrm{X} \rightarrow \mathrm{Y} \\
\text { Dolaylı Etki) }\end{array}$} \\
\hline$\beta$ & $\begin{array}{l}\text { LLCI- } \\
\text { ULCI }\end{array}$ & $\beta$ & LLCI-ULCI & $\beta$ & LLCI-ULCI & $\beta$ & LLCI-ULCI & $\beta$ & $\begin{array}{l}\text { BootLLCI- } \\
\text { BootULCI }\end{array}$ \\
\hline$-0,20$ & $\begin{array}{c}-0,288- \\
0,115 \\
\mathrm{p}=0,000\end{array}$ & $-0,13$ & $\begin{array}{c}-0,236- \\
0,017 \\
p=0,023\end{array}$ & 0,45 & $\begin{array}{c}0,352 \\
0,543 \\
p=0,000\end{array}$ & 0,42 & $\begin{array}{c}0,325 \\
0,520 \\
p=0,000\end{array}$ & 0,03 & $\begin{array}{l}0,0002 \\
0,0574\end{array}$ \\
\hline De & $\begin{array}{l}2 \mathrm{a}= \\
\text { eklendi }\end{array}$ & & $\begin{array}{c}\mathrm{H} 3 \mathrm{a}= \\
\text { esteklendi }\end{array}$ & & $\begin{array}{c}\mathrm{H} 1= \\
\text { esteklendi }\end{array}$ & & & & $\begin{array}{c}\mathrm{H} 4 \mathrm{a}= \\
\text { Desteklendi }\end{array}$ \\
\hline
\end{tabular}

Bağımsız Değişken: Etkileşimsel Adalet (X), Bağımlı Değişken: Seslilik Davranışı (Y), Aracı Değişken: Korku (M1). * Toplam etkiye (c yolu) ait değerler, PROCESS Model 4 kullanılarak hesaplanmıştır.

Tablo 4'teki Process ile yapılan regresyon analizinde, etkileşimsel adaletin çalışanların seslilik davranışını $(\beta=$ 0,$45 ; t=9,2168 ; p<0,01$ ) pozitif ve istatistiksel olarak anlamlı bir şekilde etkilediği ortaya çıkmıştır (c yolu). Dolayısıyla H1 hipotezi desteklenmiştir. Bununla birlikte, etkileşimsel adaletin korku duygusunu ( $\beta=-0,20$; $\mathrm{t}=$ -4,5770; $p<0,01$ ) negatif ve istatistiksel olarak anlamlı bir şekilde etkilediği ortaya çıkmış (a yolu); H2a hipotezi de desteklenmiştir. Aracı değişkenin bağımlı değişkene etkisi incelediğinde ise korku duygusunun seslilik davranışını $(\beta=-0,13 ; \mathrm{t}=-2,2857 ; p<0,01)$ negatif ve istatistiksel olarak anlamlı bir şekilde etkilediği ortaya çıkmış (b yolu); H3a hipotezi desteklenmiştir. Etkileşimsel adaletin korku duygusu ile birlikte seslilik davranışı üzerine etkisine bakıldığında ise etkileşimsel adaletin 0,45 pozitif beta etkisi, korku duygusunun devreye girmesiyle 0,03 azalarak 0,42 betaya düşmüştür. Tablo 4 'teki sonuçlarda Bootstrap güven aralığının alt ve üst sınırının (BootLLCI - BootULCI) sıfırın üstünde kaldığı görülmüştür $((0,0002)-(0,0574))$. Böylece korku duygusunun kısmi aracılık etkisine sahip olduğu ifade edilebilir. Korku duygusunun aracilık etkisi, Sobel testi ile de kontrol edilmiştir. Yapılan işlemde $Z$ değerinin $(2,31, p<0,05) 1,96$ 'dan büyük ve anlamlı olduğu görülerek söz konusu aracılık etkinin anlamlı olduğu tespit edilmiştir. Dolayısıyla H4a hipotezi desteklenmiştir.

Tablo 5. Kızgınlık Duygusunun Aracilık Etkisi

\begin{tabular}{|c|c|c|c|c|c|c|c|c|c|}
\hline \multicolumn{2}{|c|}{$\begin{array}{c}\text { a yolu } \\
(\mathrm{X} \rightarrow \mathrm{M} 2)\end{array}$} & \multicolumn{2}{|r|}{$\begin{array}{l}\text { b yolu } \\
(\mathrm{M} \rightarrow \mathrm{Y})\end{array}$} & \multicolumn{2}{|c|}{$\begin{array}{c}\text { c yolu } \\
(X \rightarrow Y \\
\text { Toplam Etki*) }\end{array}$} & \multicolumn{2}{|c|}{$\begin{array}{c}\mathrm{c}^{\prime} \text { yolu } \\
(X \rightarrow Y \\
\text { Doğrudan Etki })\end{array}$} & \multicolumn{2}{|c|}{$\begin{array}{c}(\mathrm{X} \rightarrow \mathrm{Y} \\
\text { Dolaylı Etki) }\end{array}$} \\
\hline$\beta$ & $\begin{array}{l}\text { LLCI- } \\
\text { ULCI }\end{array}$ & $\beta$ & LLCI-ULCI & $\beta$ & LLCI-ULCI & $\beta$ & LLCI-ULCI & $\beta$ & $\begin{array}{l}\text { BootLLCI- } \\
\text { BootULCI }\end{array}$ \\
\hline$-0,15$ & $\begin{array}{c}-0,257- \\
0,041 \\
\mathrm{p}=0,007\end{array}$ & $-0,11$ & $\begin{array}{c}-0,199- \\
0,024 \\
\mathrm{p}=0,012\end{array}$ & 0,45 & $\begin{array}{c}0,352 \\
0,543 \\
\mathrm{p}=0,000\end{array}$ & 0,43 & $\begin{array}{c}0,335 \\
0,527 \\
\mathrm{p}=0,000\end{array}$ & 0,02 & $\begin{array}{l}0,0009 \\
0,0483\end{array}$ \\
\hline Des & $\begin{array}{l}\mathrm{I} 2 \mathrm{~b}= \\
\text { eklendi }\end{array}$ & & $\begin{array}{l}\mathrm{H} 3 \mathrm{~b}= \\
\text { esteklendi }\end{array}$ & & $\begin{array}{l}\mathrm{H} 1= \\
\text { esteklendi }\end{array}$ & & & & $\begin{array}{l}\mathrm{H} 4 \mathrm{~b}= \\
\text { steklendi }\end{array}$ \\
\hline
\end{tabular}

Bağımsız Değişken: Etkileşimsel Adalet (X), Bağımlı Değişken: Seslilik Davranışı (Y), Aracı Değişken: Kızgınlık (M2). * Toplam etkiye (c yolu) ait değerler, PROCESS Model 4 kullanılarak hesaplanmıştır.

Tablo 5 'teki Process ile yapılan regresyon analizinde, etkileşimsel adaletin çalışanların seslilik davranışını $(\beta=$ 0,$45 ; t=9,2168 ; p<0,01$ ) pozitif ve istatistiksel olarak anlamlı bir şekilde etkilediği ortaya çıkmıştır (c yolu). Bununla birlikte, etkileşimsel adaletin kızgınlık duygusunu $(\beta=-0,15 ; t=-2,7108 ; p<0,01)$ negatif ve istatistiksel olarak anlamlı bir şekilde etkilediği ortaya çıkmış (a yolu); H2b hipotezi desteklenmiştir. Aracı değişkenin bağımlı değişkene etkisi incelediğinde ise kızgınlık duygusunun seslilik davranışını $(\beta=-0,11 ; t=-2,5113$; $\mathrm{p}<0,01)$ negatif ve istatistiksel olarak anlamlı bir şekilde etkilediği ortaya çıkmış (b yolu); H3b hipotezi desteklenmiştir. Etkileşimsel adaletin kızgınlık duygusu ile birlikte seslilik davranışı üzerine etkisine 


\section{A. Acaray $12 / 1(2020) 663-675$}

bakıldığında ise etkileşimsel adaletin 0,45 pozitif beta etkisi, kızgınlık duygusunun devreye girmesiyle 0,02 azalarak 0,43 betaya düşmüştür. Tablo 5 'teki sonuçlarda Bootstrap güven aralığının alt ve üst sınırının (BootLLCI - BootULCI) sıfırın üstünde kaldığı görülmüştür $((0,0009)-(0,0483))$. Böylece kızgınlık duygusunun kısmi aracılık etkisine sahip olduğu ifade edilebilir. Kızgınlık duygusunun aracılık etkisi, Sobel testi ile de kontrol edilmiştir. Yapılan işlemde $Z$ değerinin $(2,02, p<0,05)$ 1,96' dan büyük ve anlamlı olduğu görülerek söz konusu aracılık etkinin anlamlı olduğu tespit edilmiştir. Dolayısıyla H4b hipotezi desteklenmiştir.

\section{Sonuç, Tartışma ve Öneriler}

Rekabet ortamının artması, örgütlerin çalışanlarından görev tanımlarında yer almayan davranışlar da sergilemelerini beklemesine yol açmıştır. Yazında gönüllü davranışlardan biri olarak ele alınan seslilik davranışı, çalışanların mevcut durumu iyileştirmek için örgütün karar alma süreçlerine katılmasını, gerekli koşullarda insiyatif almasını, görüş ve öneriler sunmasını ve bilgilerini paylaşmasını içermekte olup (Eryeşil, 2018), rekabet avantajının oluşumu ve korunmasında önemli bir davranıştır. Bu davranışın ortaya çıkması, temelde yönetici ile çalışan arasındaki iletişim ve etkileşimin niteliğine bağlıdır. Niteliği artıran faktörlerden biri de, örgütlerde alınan kararlarla ilgili yöneticilerin gerekli açıklamaları yapıp yapmadığı ve açıklamaların yapılmasında saygılı olup olmadığının çalışanlarda oluşturduğu etkileşimsel adalet algısıdır. Dolayısıyla bilgilerin dağıtımı ve dağıtım esnasında karşılaşılan muameleler, çeşitli duygusal tepkileri açığa çıkararak yaşanılan eşitsizlik gerilimine bağlı olarak, çalışanlar gerilimi azaltıcı davranışlar içerisine girecektir. Bu bağlamda yapılan çalışmada, korku ve kızgınlık gibi negatif duyguların, etkileşimsel adalet ile çalışanların seslilik davranışları ilişkisindeki aracılık etkisi bankacılık sektörü örneklemi üzerinde incelenmiştir.

Çalışanların, araştırmanın temel değişkenlerine ilişkin sahip oldukları algılamalarına bakıldığında, etkileşimsel adalet algılamalarının ve seslilik davranışlarının ise orta düzeyin üzerinde olduğu tespit edilmiştir. Ayrıca çalışanların orta düzeye yakın kızgınlık duygusu ve düşük düzeyde ise korku duygusu içerisinde oldukları ortaya çıkmıştır.

Çalışmanın temel değişkenleri arasındaki bulgu, etkileşimsel adaletin çalışanların seslilik davranışlarını artırdığına ilişkin sonuçtur. Çalışanlar, yöneticileri ile arasındaki iletişimde eşitlik algıladıklarında, pozitif algılamalara sahip olduklarında örgüte sundukları çabaları artırma yoluna gidecektir. Bu durum sosyal değişim teorisi (Blau, 1964) perspektifinden de, çalışanların algıladıkları olumlu durumlara seslilik davranışlarını artırarak karşılık verdikleri şeklinde ifade edilebilir. Dolayısıyla çalışmanın bu bulgusu, sosyal değişim teorisinin varsayımına da destek sağlamaktadır. Ayrıca söz konusu bulgu, yazındaki (Eryeşil, 2018; Yeşil vd., 2018; Eroğluer ve Erselcan, 2017; Dustar ve Esmailzadeh, 2014; Takeuchi vd., 2012; Demirel ve Seçkin, 2011; Şeşen ve Basım, 2010; VanYperen vd., 2000) çalışmaların sonuçları ile de tutarlıdır.

Etkileşimsel adalet çalışanların negatif duygularını (korku ve kızgınlık) azaltmıştır. Örgütlerde kararların alınmasındaki bilgilerin dağıtımı ve dağıtımın açılanmasında saygılı, dürüst ve nazik olunmasına dair çalışanların adalet algıları onların kızgınlıkları ve korkularını azaltarak önemli bir gerilimden kurtarmıştır. Çalışanlar eğer adaletsizlik algılamasına sahiplerse ise kızgınlıkları ve korkuları ortaya çıkabilecek ve bir gerilim hali yaşayabileceklerdir. Ulaşılan bu sonuç da, Polatcı ve Özçalık (2015), Roy ve arkadaşları (2012), Fox ve arkadaşları (2001) ve Skarlicki ve Folger (1997) tarafından yapılan çalışmalarda ulaşılan sonuçları desteklemektedir.

Negatif duyguların (korku ve kızgınlık) çalışanların seslilikleri üzerinde negatif bir etkiye sahip olduğu ortaya çıkan sonuçlardan bir diğeridir. Çalışanın örgüt içerisindeki uygulamalar neticesinde korku ve kızgınlık duyguları, onların örgüt lehine yararlı eylemlerden uzaklaşmasına neden olmuştur. Örneğin, seslilik davranışının ortaya çıııp çıkmamasında önemli faktörlerden birisi, korku duygusunun varlığıdır. Çünkü çalışan, seslendirilen durumun neticesinde çeşitli olumsuzluklarla karşılaşabilmektedir. Bu durumla yüzleşmemek için seslilik davranışını azaltabilmekte ya da geri çekebilmektedir. Erol-Korkmaz (2014) da, tecrübe edilen olumsuz duyguların olumsuz iş davranışlarına yol açabileceğini ifade etmiştir.

Korku ve kızgınlık gibi negatif duyguların, etkileşimsel adalet ile seslilik davranışları arasındaki ilişkide kısmi aracılık etkisine sahip olduğu ulaşılan diğer bir bulgudur. Etkileşimsel adaletin seslilik davranışlarına olan pozitif etkisi kısmi olarak negatif duygular vasıtasıyla azalmıştır. Diğer bir ifade ile çalışanlar etkileşimsel adaleti (bilgisel ve kişilerarası adalet) olumsuz olarak hissettiklerinde, kızgınlık ve korku duyguları harekete geçmekte ve bu negatif duygular da gönüllü olarak gerçekleştirdikleri seslilik davranışlarını azaltmaktadır. 


\section{A. Acaray $12 / 1(2020) 663-675$}

Etkileşimsel adalete ilişkin olumsuz algılar, çalışanların negatif duygularını artırarak seslilik davranışlarının geri çekilmesine yol açabilmektedir. Dolayısıyla adaletsizlik, çalışanların negatif duygularını ortaya çıkararak seslilik davranışlarını olumsuz etkileyebilmektedir.

Çalışanların seslilik davranışlarının artırılmasında etkileşimsel adaletin önemli bir yönetsel durum olarak ortaya çıkması, yöneticilerin uygulamalarda odaklanacakları konuyu işaret etmiştir. Yöneticilerin hem bilgisel adaletin hem de kişilerarası adaletin sağlanması adına temelde yapacakları şudur: çalışanlara alınan kararlarla ilgili açıklama yapmaları ve onların bu konuda olabilecek endişelerinin giderilmesinde saygılı olmalarıdır. Dolayısıyla ilişkinin nitelikli hale getirilmesi gerekmektedir. Etkileşime ilişkin adaletsizlik algısı ortaya çıkarsa, çalışanların negatif duyguları ortaya çıkabilecek ve bu durumda da negatif duyguların yönetimi önemli bir sorun haline gelebilecektir. Özellikle korku ve kızgınlık duygusu içerisindeki çalışanın, bu duygularıyla baş edebilmesi duygu yönetimi konusundaki zekâsına bağlıdır. Bu bağlamda da çalışanların duygusal zekâlarının geliştirilmesi için eğitimler verilmesi konusu ortaya çıkabilecek ve örgütün maliyeti artabilecektir. Diğer taraftan ise negatif duyguların yönetilememesi halinde örgütün aleyhine çalışanların davranışsal tepkilerinin yıkıcı olabileceği mümkündür. Dolayısıyla, çalışanlar seslilik davranışlarını azaltma yanında başka olumsuz iş davranışlarını da ortaya çıkarabilecekler ve örgütün karşılaşabileceği olumsuz sonuçlar artabilecektir.

Diğer uygulamalı çalışmalarda olduğu üzere bu çalışmada da, örneklemin sadece bir ilin bankacılık sektörü çalışanlarından seçilmesi önemli bir sınırlılığı oluşturmaktadır. Ulaşılan sonuçların sektöre yönelik genelleme yapmadan sadece bu örneklem dahilinde değerlendirilmesi önemlidir. Daha sonra bu konularda araştırma yapmayı düşünenler, dağıtımsal, prosedürel ve etkileşimsel adalet algılarının örgütsel vatandaşlık davranışı ile üretkenlik karşıtı iş davranışlarına etkisinde negatif duyguların aracılık, duygusal zeka ya da duygu düzenleme stratejilerinin düzenleyici değişken etkilerini eğitim sektörü çalışanları üzerinde inceleyebilirler.

\section{Kaynakça}

Adams, J.S. (1963). Toward an understanding of inequity, Journal of Abnormal and Social Psychology, 67, 422-436.

Adams, J.S. (1965). Inequity in social exchange, in Berkowitz, L. (Ed.), Advances in experimental social psychology, New York: Academic Press, 267-299.

Arslan, A. ve Yener, S. (2016). İşgören sesliliği ölçeğinin Türkçeye uyarlanması çalışması, Yönetim ve Ekonomi Araştırmaları Dergisi, 14 (1), 173-191.

Baron, R.M. and Kenny, D.A. (1986). The moderator-mediator variable distinction in social psychological research: Conceptual, strategic, and statistical considerations, Journal of Personality and Social Psychology, $51(6), 1173-1182$.

Barutçugil, İ. (2004). Organizasyonlarda duyguların yönetimi, İstanbul: Kariyer Yayınları.

Bies, R.J. (2001). Interactional justice: The sacred and the profane, in Greenberg J. ve Crapanzano, R. (Ed.) Advances in organizational justice, Stanford University Pres., 89-118.

Bies, R.J. and Moag, J.F. (1986). Interactional justice: Communication criteria of fairness, in R.J. Lewicki, B.H. Sheppard and M.H. Bazerman (Eds.), Research on negotiations in organizations, Greenwich, CT: JAI Press, 1, 43-55.

Blau, P.M. (1964). Exchange and power in social life, New York: Wiley.

Botero, I.C. and Van Dyne, L. (2009). Employee voice behavior interactive effects of LMX and power distance in the United States and Colombia, Management Communication Quarterly, 23 (1), 84-104.

Colquitt, J. A. (2001). On the dimensionality of organizational justice: A construct validation of a measure, Journal of Applied Psychology, 86 (3), 386-400.

Çetin, Ş. ve Çakmakçı, C. (2012). Çalışan sesliliği ölçeğini Türkçeye uyarlama çalışması, KHO Bilim Dergisi, 22 (2), 1-19.

Demirel, Y. ve Seçkin, Z. (2011). Örgütsel adaletin bilgi paylaşımı üzerine etkisi: İlaç sektörü çalışanlarına yönelik bir araştırma, Bilig, 56, 99-119. 


\section{A. Acaray $12 / 1(2020) 663-675$}

Derin, N. (2017). İşyerinde kişiler arası güven ile işgören sesliliği arasındaki ilişkide psikolojik rahatlı̆̆ın aracilık rolü, Yönetim Bilimleri Dergisi, 15 (30), 51-68.

Detert, J.R. and Burris, E.R. (2007). Leadership behavior and employee voice: Is the door really open?, Academy of Management Journal, 50, 869-884.

Detert, J.R. and Edmondson, A.C. (2011). Implicit voice theories: Taken-for-granted rules of selfcensorship at work, Academy of Management Journal, 54, 461-488.

Durak, İ. (2013). Yöneticilerle açıç̧a konuşabilme düzeyinin genel konuşma nedenlerine etkisi: Üniversitelerde bir araştırma, Erciyes Üniversitesi İ̈BF Dergisi, 41, 111-136.

Dustar, M. and Esmailzadeh, M. (2014). Organizational justice and its effects on employees voice and performance, Journal of Management Studies In Development \& Evaluation, Winter 23 (72), 143-163.

Eroğluer, K. ve Erselcan, R.C. (2017). Çalışanların örgütsel adalet algısı ve tükenmişlik düzeylerinin çalışan sessizliği üzerindeki etkisi, Business and Economics Research Journal, 8 (2), 325-348.

Erol-Korkmaz, H.T. (2014). Çalışanların günlük duygu durumu ve üretim karşıtı davranışları arasındaki ilişki: Genel örgütsel adalet algısının düzenleyici rolü, Türk Psikoloji Yazıları, 17 (33), 77-87.

Eryeşil, K. (2018). Algılanan örgütsel adaletin örgütsel muhalefet üzerindeki etkisinde çalışan sesliliğinin rolü: Bankacılık sektöründe bir araştırma, Yayımlanmamış Doktora Tezi, Selçuk Üniversitesi, SBE, Konya.

Field, A.P. (2000). Discovering statistics using spss for windows, London: Sage Publications.

Fox, S., Spector, P. E. and Miles, D. (2001). Counterproductive work behavior (cwb) in response to job stressors and organizational justice: Some mediator and moderator tests for autonomy and emotions, Journal of Vocational Behavior, 59, 291-309.

Gaudreau, P., Blondin, J.P. and Sanchez, X. (2003). Positive and negative affective states in a performancerelated setting: Testing the factorial validity of the panas across two samples of French-Canadian participants, European Journal of Psychological Assessment, 22, 240-249.

Greenberg, J. and Colquitt, J.A. (2005). The handbook of organizational justice, Mahwah, NJ: Erlbaum.

Greenberg, J. (1993). Stealing in the name of justice: Informational and interpersonal moderators of theft reactions to underpayment inequity, Organizational Behavior and Human Decision Processes, 54, 81-103.

Güzel, B. ve Ayazlar, G. (2014). Örgütsel adaletin örgütsel sinizm ve işten ayrılma niyetine etkisi: Otel işletmeleri araştırması, KMÜ Sosyal ve Ekonomik Araştırmalar Dergisi, 16 (26), 133-142.

Haşıloğlu, S.B., Baran, T. ve Aydın, O. (2015). Pazarlama araştırmalarındaki potansiyel problemlere yönelik bir araştırma: Kolayda örnekleme ve sıklık ifadeli ölçek maddeleri, Pamukkale Işsletme ve Bilişim Yönetimi Dergisi, 2 (1), 19-28.

Hayes, A.F. (2013). Introduction to mediation, moderation, and conditional process analysis: A regression-based approach, New York, NY: The Guilford Press.

Hirschman, A. O. (1970). Exit, voice and loyalty; responses to decline in firms, organizations and states, M.A: Harward University Pres, Cambridge.

İçerli, L. (2010). Örgütsel adalet: Kuramsal bir yaklaşım, Girişimcilik ve Kalkınma Dergisi, 1 (5), 67-92.

İşbaşı, J.Ö. (2001). Çalışanların yöneticilerine duydukları güvenin ve örgütsel adalete ilişkin algılamalarının vatandaşlık davranışının oluşumundaki rolü, Yönetim Araştırmaları Dergisi, 1 (1), 51-73.

Kalaycı, Ş. (2008). Spss uygulamalı çok değişkenli istatistik teknikleri, 3. Baskı, Ankara: Asil Yayın Dağıtım.

Malhotra, N.K. (2004). Marketing research an applied orientation, 4. Edition. New Jersey: Pearson Prentice Hall.

Mcshane, S.L. and Von Glinow, M.A. (2014). Organizational behavior, 2. Edition. NewYork: McGraw-Hill/Irwin.

Morrison, E.W. and Milliken, F.J. (2000). Organizational silence: A barrier to change and development in a pluralistic world, Academy of Management Review, 25, 706-725. 


\section{A. Acaray $12 / 1(2020) 663-675$}

Nikolaou, I., Vakola, M. and Bourantas, D. (2008). Who speaks up at work? Dispositional influences on employees' voice behavior, Personnel Review, 37 (6), 666-679.

Özbek, F. (2004). İnsan ilişkilerinde güvenin yeri ve önemi, İş, Güç Endüstri İlişkileri ve İnsan Kaynakları Dergisi, $6(1)$.

Özçınar, M.F., Demirel, Y. ve Özbezek, B.D. (2015). Çalışanların örgütsel adalet algıları ve örgütsel sessizlik arasındaki ilişkinin incelenmesi, Mehmet Akif Ersoy Üniversitesi Sosyal Bilimler Enstitüsü Dergisi, 7 (13), 150171.

Özdevecioğlu, M. (2004). Duygusal olaylar teorisi çerçevesinde pozitif ve negatif duygusallığın algılanan örgütsel adalet üzerindeki etkilerini belirlemeye yönelik bir araştırma, Ankara Üniversitesi SBF Dergisi, 59 (3), 181-202.

Özdevecioğlu, M. (2003). Algılanan örgütsel adaletin bireylerarası saldırgan davranışlar üzerindeki etkilerinin belirlenmesine yönelik bir araştırma, Erciyes Üniversitesi İIBF Dergisi, 21, 77-96.

Özkalp, E. ve Cengiz, A.A. (2003). İşyerinde duygular ve yönetimi, 11. Ulusal Yönetim ve Organizasyon Kongresi, Afyon, 943-955.

Özmen, Ö. N.T., Arbak, Y. ve Özer, P.S (2007). Adalete verilen değerin adalet algıları üzerindeki etkisinin sorgulanmasına ilişkin bir araştırma, Ege Akademik Bakış, 7 (1), 17-33.

Polatcı, S. ve Özçalık, F. (2015). Çalışanların örgütsel adalet algıları ile üretkenlik karşıtı iş davranışları etkileşiminde pozitif ve negatif duygusallığın aracılık etkisi, Dokuz Eylül Üniversitesi Sosyal Bilimler Enstitüsü Dergisi, 17 (2), 215-234.

Roy, J.L., Bastounis, M. and Minibas-Poussard, J. (2012). Interactional justice and counterproductive work behaviors: The mediating role of negative emotions, Social Behavior And Personality, 40 (8), 1341-1356.

Skarlicki, D.P. and Folger, R. (1997). Retaliation in the orkplace: The roles of distributive, procedural, and interactional justice, Journal of Applied Psychology, 82, 434-443.

Şeşen, H. (2010). Adalet algısının tükenmişliğe etkisi: İş tatmininin aracı değişken rolünün yapısal eşitlik modeli ile testi, Savunma Bilimleri Dergisi, 2 (9), 67-90.

Şeşen, H. ve Basım, H.N. (2010). Çalışanların adalet algısının örgütsel vatandaşlık davranışlarına etkisi: İş tatmininin aracılık rolü, ODTÜ Gelişme Dergisi, 37, 171-193.

Takeuchi, R., Chen, Z. and Cheun, S.Y. (2012). Applying uncertainty management theory to employee voice behavior: An integrative investigation, Personnel Psychology, 65, 283-323.

Thibaut, J. and Walker, L. (1975). Procedural justice: A psychological analysis, Hillsdale, N.J.: Erlbaum.

Töremen, F. ve Çankaya, İ. (2008). Yönetimde etkili bir yaklaşım: Duygu yönetimi, Kuramsal Ĕ̆itimbilim, 1 (1), 33-47.

Uslu, S. ve Aktaş, H. (2017). İşten ayrılma niyeti ile örgütsel sessizlik etkileşiminde iş güvencesi memnuniyeti ve iş güvencesi endeksinin aracı rolü: Özel bir hastane çalışanları üzerinde bir araştırma, Eskişehir Osmangazi Üniversitesi İ̈BF Dergisi, 12 (1), 141-160.

Van Dyne, L. and LePine, J.A. (1998). Helping and voice extra-role behavior: Evidence of construct and predictive validity, Academy of Management Journal, 41, 108-119.

VanYperen, N.W., Hagedoorn, M., Zweers, M. and Postma, S. (2000). Injustice and employees' destructive responses: The mediating role of state negative affect, Social Justice Research, 13, 291-312.

Weiss, H.M. and Cropanzano, R. (1996). Affective events theory: A theoretical discussion of the structure, cases and consequences of affective experiences at work, Research in Organizational Behavior, 18, 1-74.

Yazıcıoğlu, Y. ve Erdoğan, S. (2004). Spss uygulamalı bilimsel araştırma yöntemleri, Ankara: Detay Yayıncılık.

Yeşil, H., Ünler, E. ve Erkuş, A. (2018). Örgütsel adalet ile çalışan sessizliği arasındaki ilişkide lider-üye etkileşiminin düzenleyici rolü, 6. Örgütsel Davranış Kongresi Bildiriler Kitabı, 2-3 Kasım, Isparta, 704-712. 